\title{
MENGENALKAN BERITA KONTEMPORER \\ DALAM PEMBELAJARAN BAHASA INDONESIA
}

\author{
Degita Danur Suharsono \\ Universitas Negeri Malang, ddanurs@gmail.com
}

\begin{abstract}
The studies development jurnalitik and digitalisasi mass media indirectly have gave rise to the form of new journalism, named contemporary journalism. Contemporary journalism is a form of journalism the present time without there was a limit. One of the products of journalism contemporary is the news contemporary. News having some kind of contemporary, among others news residents, online news, and the advertorial.In education sector, news is one of text that learned at 2013 curriculum class XII high school. This paper aimed to introduce and develop the form of and types of text news contemporary in learning the Indonesian language. With the contemporary news, learning text news in school is expected to be more varied. Contemporary news also expected to capable of being a innovation learning the indonesian language in the future now. In addition, contemporary news can be realizing one of the programs of 14 kreativ economic program.
\end{abstract}

Key words: contemporary news, learning, Indonesia language

\section{PENDAHULUAN}

Jurnalistik dapat diartikan sebagai kegiatan mencari, menulis, dan memublikasikan berita kepada khalayak luas. Dalam perkembangannya, dunia jurnalistik menghasilkan ragam baru dalam pemberitaannya. Ragam jurnalistik baru muncul karena kebosanan wartawan senior di Amerika tahun 1960-an terhadap standar baku dalam penulisan berita (Setiati, 2005:43).

Berita merupakan salah satu bentuk tulisan jurnalistik (Saryono, 1997). Secara umum, berita dapat dikatakan sebagai tulisan mengenai fakta yang bersifat umum dan disampaikan oleh wartawan di media massa. Berdasarkan bentuk penyampaiannya, berita dibagi menjadi dua jenis yaitu berita tertulis dan berita siaran. Bentuk berita tertulis merupakan berita yang ditulis di surat kabar (koran, majalah, atau portal online), sedangkan berita siaran adalah berita yang disiarkan melalui radio, televisi, atau portal online. 
Paradigma mengenai berita mengalami perkembangan yang pesat. Pemikiran, konsep, dan ide baru mengenai berita terus bermunculan. Salah satu konsep yang muncul adalah berita kontemporer. Secara harfiah, berita kontemporer terdiri dari dua frasa, yaitu berita dan kontemporer. Sumadiria (2008:65) mendefinisikan berita sebagai laporan tercepat mengenaifakta atau ide terbaru yang benar, menarik, dan penting bagi sebagian besar khalayak. Sementara itu, kontemporer dapat diartikan pada masa kini. Pada makalah ini, penulis membatasi kata kontemporer pada hal yang identik dan berkaitan erat dengan internet. Dengan demikian, berita kontemporer adalah laporan tercepat mengenai suatu peritiwa yang disampaikan ke khalayak dengan menggunakan media internet.

Dalam dunia pendidikan, berita telah lama menjadi salah satu materi pembelajaran bahasa Indonesia. Pada Kurikulum 2013, teks berita merupakan teks yang dipelajari oleh siswa kelas XII SMA. Berita kontemporer sebagai salah satu pembaharuan dan pengembangan dalam materi pembelajaran teks berita dapat dijadikan satu pilihan guru dan siswa di sekolah. Berita kontemporer akan mengajak siswa lebih kreatif dan inovatif dalam belajar teks berita. Oleh karena itu, makalah ini mengenalkan konsep, karakteristik, dan jenis berita kontemporer.

\section{PEMBAHASAN}

Berita kontemporer tidak terpisahkan dari konsep jurnalisme kontemporer. Jurnalisme kontemporer atau jurnalisme masa kini merupakan praktik kewartawanan dengan model terkini. Saat ini model penyampaian informasi dipermudah dengan hadirnya internet. Secara tidak langsung, internet telah mempengaruhi praktik mencari, mengumpulkan, mengedit, dan menyebarluaskan berita dengan transformasi informasi menggunakan internet.

Menurut Kovach dan Rosentiel (2001) mengemukakan sembilan elemen pada jurnalisme kontemporer. Adapun yang pertama adalah menyampaikan kekuasaan. Kedua, memiliki loyalitas kepada masyarakat. Ketiga, memiliki disiplin untuk melakukan verivikasi. Keempat, memiliki kemandirian terhadap apa yang diliputnya. Kelima, memiliki kemandirian untuk memantau kekuasaan. Keenam, menjadi forum bagi kritik dan kesepakatan publik. Ketujuh, menyampaikan sesuatu secara menarik dan relevan kepada publik. Kedelapan, membuat berita secara komprehensif dan proposional. Kesembilan, memberi kekuasaan wartawan untuk mengikuti nurani mereka. Dalam 
makalah ini penulis menambahkan dua elemen jurnalisme kontemporer, yakni menyampaikan suatu hal yang tidak bertentangan dengan etika dan menyampaikan informasi secara cept, akurat, serta menarik. Elemen-elemen jurnalisme kontemporer ini dapat digunakan sebagai basis dalam mempelajari berita kontemporer.

Bentuk berita kontemporer bukanlah upaya untuk menggantikan berita konvensional. Berita konvensional dan berita kontemporer pada hakikatnya berhubungan dan saling melengkapi. Berita kontemporer disampaikan secara singkat dan tidak mendalam, sedangkan berita konvensional disampaikan secara jelas, menyeluruh, dan mendalam. Asmuruf (2015) mengatakan berita berhubungan erat dengan media, media kontemporer dan media konvensional dikatakan saling melengkapi karena ketika suatu berita ditulis secara singkat dan tidak mendalam di media kontemporer, kemungkinan besar orang akan mencari sumber berita lain untuk melengkapi berita yang dirasa belum mendalam pada media kontemporer.

Kemunculan berita kontemporer tidak hanya membawa dampak baik, namun juga membawa dapak tidak baik bagi transformasi informasi. Ada beberapa dampak baik berita kontemporer, yakni (1) akses internet membantu khalayak umum dalam mengakses informasi secara cepat, (2) publik dapat memberi tanggapan pada berita yang disampaikan, (3) semua orang dapat menyampaikan berita, dengan begitu setiap peristiwa penting di daerah dapat disampaikan dengan cepat. Selain itu, ada juga dampak tidak baik munculnya berita kontemporer, yakni (1) tidak adanya filter bagi berita yang disampaikan mengakibatkan berita yang disampaikan diragukan kebenarannya, (2) unsur subjektif atau opini penulis (bukan wartawan) masih sering dijumpai dalam berita, dan (3) isi berita seringkali kurang berbobot.

Berdasarkan Kurikulum 2013, teks berita merupakan salah satu teks yang dipelajari pada kelas XII SMA. Melihat jenjang pendidikan tersebut, penerapan berita kontemporer dalam pembelajaran bahasa Indonesia perlu kiranya dilakukan. Berita kontemporer dapat digunakan sebagai inovasi mutakhir dalam pembelajaran bahasa Indonesia di era globalisasi. Dengan adanya berita kontemporer diharapkan pembelajaran bahasa Indonesia, khususnya materi pembelajaran teks berita, dapat digunakan sebagai wahana mewujudkan program ekonomi kreatif pemerintah, yaitu penerbitan dan percetakan. 
Sama halnya dengan teks berita lainya, berita kontemporer juga memiliki beberapa karakteristik seperti dalam Tabel 1. Karakteristik ini digunakan sebagai ciri khusus atau penanda berita kontemporer dengan berita konvensional.

Tabel 1

\begin{tabular}{|c|c|c|c|}
\hline No. & Berita Konvensional & Berita Kontemporer & Keterangan \\
\hline 1 & $\begin{array}{l}\text { Penulisan berita } \\
\text { lebih panjang dan } \\
\text { menyeluruh }\end{array}$ & $\begin{array}{l}\text { Penulisan berita } \\
\text { singkat dan padat }\end{array}$ & $\begin{array}{l}\text { Berita konvensional ditulis lebih } \\
\text { panjang dan menyeluruh karena } \\
\text { wadah yang disediakan lebih } \\
\text { banyak. Sebaliknya, berita } \\
\text { kontemporer ditulis singkat dan } \\
\text { padat karena wadah yang } \\
\text { terbatas, serta bertujuan untuk } \\
\text { membuat pembaca cepat } \\
\text { memahami isi berita. }\end{array}$ \\
\hline 2. & $\begin{array}{l}\text { Berisi konvensional } \\
\text { berisi laporan } \\
\text { peristiwa atau fakta } \\
\text { yang aktual, objektif, } \\
\text { benar, dan akurat. }\end{array}$ & $\begin{array}{l}\text { Berita kontemporer } \\
\text { berisi tentang } \\
\text { laporan peristiwa, } \\
\text { fakta, atau opini } \\
\text { publik yang aktual, } \\
\text { objektif (bisa juga } \\
\text { subjektif), benar, dan } \\
\text { akurat. }\end{array}$ & $\begin{array}{l}\text { Sama halnya dengan berita } \\
\text { konvensional, berita } \\
\text { kontemporer juga berisikan } \\
\text { tentang laporan peristiwa atau } \\
\text { fakta. Akan tetapi, berita } \\
\text { kontemporer juga dapat berisikan } \\
\text { opini publik yang bersifat } \\
\text { subjektif. Hal tersebut tidak } \\
\text { dapat dituliskan dalam berita } \\
\text { konvensional. }\end{array}$ \\
\hline 3. & $\begin{array}{l}\text { Berita konvensional } \\
\text { merupakan hasil } \\
\text { liputan jurnalistik } \\
\text { (melalui proses } \\
\text { proyeksi, observasi, } \\
\text { investigasi, } \\
\text { komunikasi, } \\
\text { wawancara, dan } \\
\text { konfirmasi dari }\end{array}$ & $\begin{array}{l}\text { Berita kontemporer } \\
\text { merupakan hasil } \\
\text { liputan jurnalistik } \\
\text { atau olahan opini } \\
\text { dan pendapat orang } \\
\text { atau publik }\end{array}$ & $\begin{array}{l}\text { Sama halnya dengan berita } \\
\text { konvensional, berita } \\
\text { kontemporer juga merupakan } \\
\text { hasil liputan jurnalistik, tetapi } \\
\text { berita kontemporer juga dapat } \\
\text { bersumber dari hasil olahan opini } \\
\text { publik }\end{array}$ \\
\hline
\end{tabular}


Degita Danur Suharsono, Mengenal Berita Kontemporer...(hal 225-239)

\begin{tabular}{|c|c|c|c|}
\hline & narasumber) & & \\
\hline 4. & $\begin{array}{l}\text { Tujuan dari berita } \\
\text { konvensional } \\
\text { sebatas untuk } \\
\text { memberi tahu dan } \\
\text { menyampaikan } \\
\text { informasi kepada } \\
\text { khalayak. }\end{array}$ & $\begin{array}{l}\text { Berita kontemporer } \\
\text { bertujuan untuk } \\
\text { menyampaikan } \\
\text { informasi dan dapat } \\
\text { digunakan untuk } \\
\text { memberikan kritik. }\end{array}$ & $\begin{array}{l}\text { Laporan berita konvensional } \\
\text { hanya sebatas memberi tahu dan } \\
\text { menyampaikan informasi kepada } \\
\text { khalayak. Berita kontemporer } \\
\text { tidak hanya memberi tahu dan } \\
\text { menyampaikan informasi tetapi } \\
\text { juga dapat digunakan untuk } \\
\text { memberikan kritik dan } \\
\text { kesepakatan publik. }\end{array}$ \\
\hline 5. & $\begin{array}{l}\text { Pemilihan jenis dan } \\
\text { gaya penulisan } \\
\text { (huruf) yang tegak- } \\
\text { lurus serta } \\
\text { mengesankan formal } \\
\text { dan kaku. }\end{array}$ & $\begin{array}{l}\text { Berita kontemporer } \\
\text { lebih memilih jenis } \\
\text { dan gaya penulisan } \\
\text { (huruf) yang } \\
\text { menarik dan kreatif }\end{array}$ & $\begin{array}{l}\text { Gaya penulisan dalam } \\
\text { kontemporer dituntut lebih luwes } \\
\text { dan non-formal untuk menarik } \\
\text { minat pembaca. }\end{array}$ \\
\hline 6. & $\begin{array}{l}\text { Berita konvensional } \\
\text { sangat terikat pada } \\
\text { kaidah tulisan } \\
\text { jurnalistik }(5 \mathrm{~W}+1 \mathrm{H}) \\
\text { selalu terletak pada } \\
\text { paragraf pertama } \\
\text { atau kedua. }\end{array}$ & $\begin{array}{l}\text { Berita kontemporer } \\
\text { boleh tidak terikat } \\
\text { dengan kaidah } \\
\text { tulisan jurnalistik, } \\
\text { dikarenakan bentuk } \\
\text { berita masa kini } \\
\text { yang lebih } \\
\text { memunculkan opini } \\
\text { publik. }\end{array}$ & $\begin{array}{l}\text { Berita kontemporer } \\
\text { diperkenankan dan } \\
\text { diperbolehkan tidak terikat pada } \\
\text { kaidah dasar tulisan jurnalistik. } \\
\text { Bentuk berita kontemporer yang } \\
\text { singkat dan padat membuat } \\
\text { pakem } 5 \mathrm{~W}+1 \mathrm{H} \text { boleh dituliskan } \\
\text { dimana saja dalam tulisan. }\end{array}$ \\
\hline 7. & $\begin{array}{l}\text { Jumlah paragraf } \\
\text { dalam berita } \\
\text { konvensional sekitar } \\
10 \text { atau lebih, } \\
\text { sedangkan jumlah } \\
\text { kata dalam satu } \\
\text { kalimat adalah } 10-15\end{array}$ & $\begin{array}{l}\text { Berita kontemporer } \\
\text { berisi antara 1-10 } \\
\text { paragraf dan jumlah } \\
\text { kata dalam satu } \\
\text { kalimat adalah 10- } \\
15 \text {. }\end{array}$ & $\begin{array}{l}\text { Paragraf yang lebih pendek } \\
\text { membuat berita kontemporer } \\
\text { dapat dibaca dalam sekali lihat } \\
\text { saja. }\end{array}$ \\
\hline
\end{tabular}




\begin{tabular}{|c|c|c|c|}
\hline & kata. & & \\
\hline 8. & $\begin{array}{l}\text { Berita konvensional } \\
\text { hanya ditulis oleh } \\
\text { wartawan atau } \\
\text { jurnalis profesional, } \\
\text { disekelsi oleh } \\
\text { redaktur dan } \\
\text { disampaikan oleh } \\
\text { media massa atau } \\
\text { kantor berita. }\end{array}$ & $\begin{array}{l}\text { Berita kontemporer } \\
\text { juga dapat ditulis } \\
\text { oleh publik yang } \\
\text { dikenal dengan } \\
\text { istilah citizen } \\
\text { journalistic. }\end{array}$ & $\begin{array}{l}\text { Sama halnya dengan berita } \\
\text { konvensional, beberapa berita } \\
\text { kontemporer juga ditulis oleh } \\
\text { wartawan, diseleksi oleh } \\
\text { radaktur, dan disampaikan oleh } \\
\text { media massa atau kantor berita, } \\
\text { tetapi berita kontemporer juga } \\
\text { dapat ditulis oleh publik. } \\
\text { Kebebasan berpendapat dan } \\
\text { kemajuan teknologi } \\
\text { memunculkan fenomena citizen } \\
\text { journalistic serta melahirkan } \\
\text { teori dari publik dan untuk } \\
\text { publik. }\end{array}$ \\
\hline
\end{tabular}

Pada Tabel 1, penulis membatasi karakteristik berita kontemporer dengan berita konvensional. Dengan penjabaran karakteristik yang membedakan berita kontemporer dengan berita konvensional, guru dan siswa dapat menggunakannya pada kompetensi dasar membedakan teks. Guru dan siswa diharapkan mengerti ciri khusus berita kontemporer dan perbedaan yang mendasar antara berita kontemporer dan berita konvensional. 
Degita Danur Suharsono, Mengenal Berita Kontemporer...(hal 225-239)

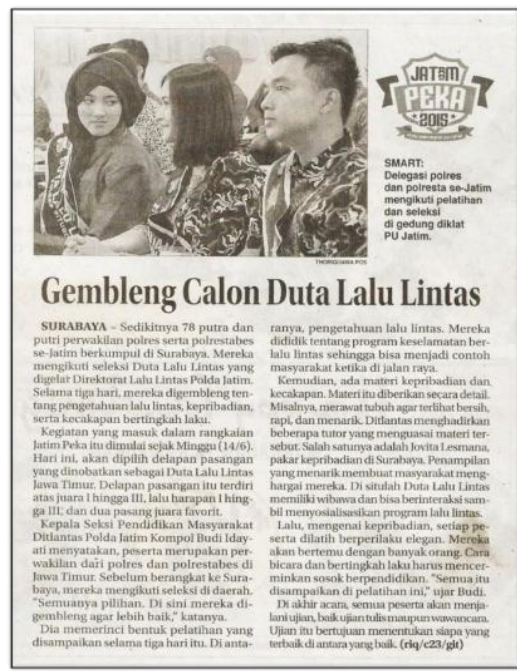

Gambar 1. Contoh berita ringkasan

(Sumber: Surya, Rubrik Malang Life, 15 Oktober 2015)

Ada beberapa jenis berita kontemporer yang dapat dipilih oleh guru dan siswa dalam pembelajaran bahasa Indonesia. Dalam makalah ini penulis membagi delapan jenis berita kontemporer, yaitu: (1) berita ringkasan, (2) berita iklan, (3) berita komik/karikatur, (4) berita kilat, (5) berita foto, (6) berita warga, (7) berita online, dan (8) berita anekdot. Masing-masing jenis berita kontemporer tersebut dijelaskan dan diberi contoh sebagai berikut.

Pertama, berita ringkasan. Berita ringkasan merupakan jenis berita dengan cara menyampaikan intisari informasi atau fakta. Tujuan berita ringkasan untuk menarik perhatian khalayak untuk melihat berita secara lebih lebih lengkap pada edisi selanjutnya atau pada bentuk online. Contoh berita ringkasan dapat dilihat pada Gambar 1.

Kedua, berita iklan. Berita iklan merupakan salah satu teknik komunikasi massa dengan membayar ruang atau waktu yang disediakan media massa untuk menyiarkan barang dan jasa yang ditawarkab oleh pemasang iklan (Schlinder dalam Suhandang, 2010:188). Dilihat dari sumber beritanya, berita iklan dibagi menjadi dua: berita iklan dari pemerintah dan berita iklan dari non pemerintah. Contoh berita iklan dapat dilihat pada Gambar 2. 


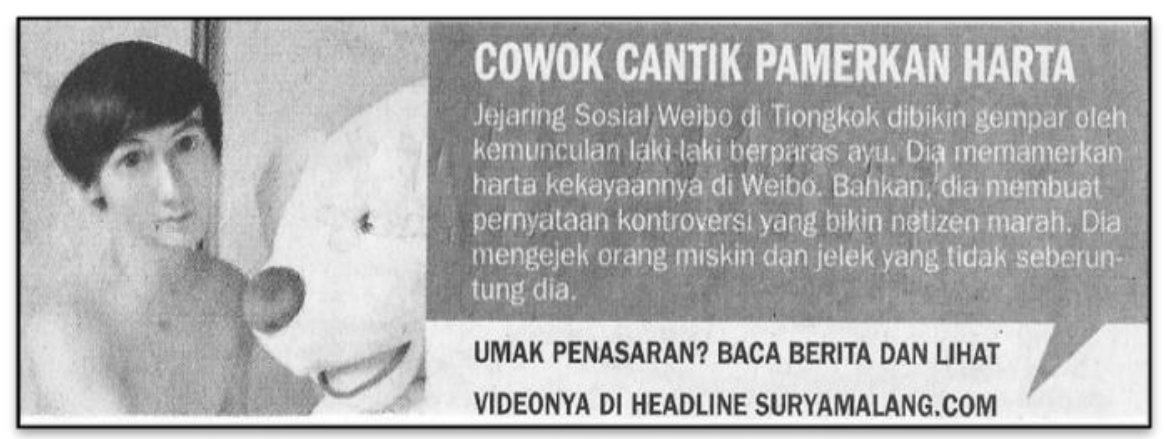

Gambar 2. Contoh berita iklan

(Sumber: Jawa Pos, 16 Juni 2015)

Ketiga, berita komik/karikatur. Berita dalam bentuk komik pertama diceritakan oleh Fauche dan letlugi, serta digambar Mori tahun 1984 dengan kisah Luckey Luke dalam sebuah komik yang berjudul Daily Star (Kurnia, 2005). Dalam perkembangannya, berita dalam bentuk komik telah ditinggalkan dan diganti dengan berita karikatur. Berita karikatur merupan bentuk penyampaian berita yang dipadukan gambar dengan cara melebih-lebihkan untuk menarik perhatian khalayak. Contoh berita komik/karikatur dapat dilihat pada Gambar 3. 


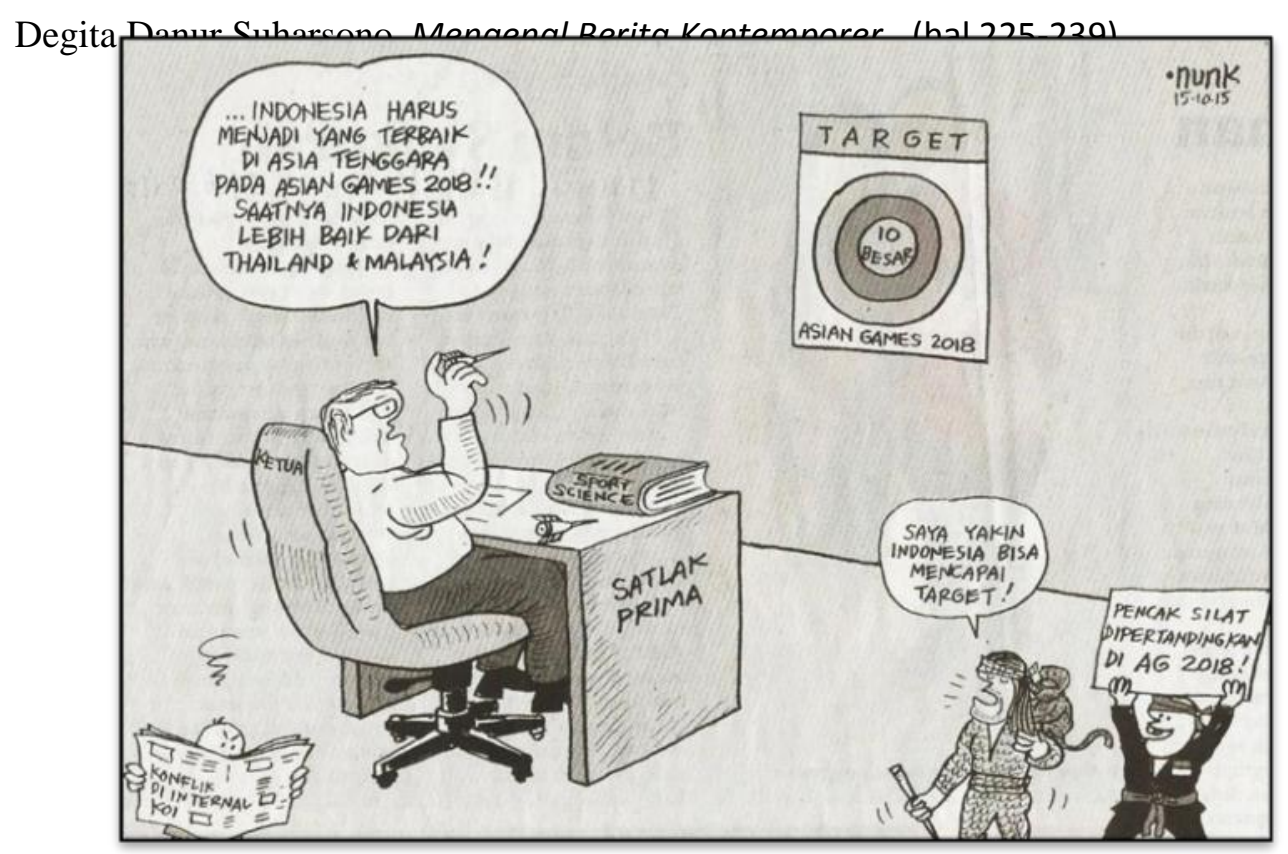

Gambar 3. Contoh berita komik/karikatur

(Sumber: Harian Bola, 15 Oktober 2015)

Keempat, berita kilat. Berita kilat merupakan bentuk penulisan berita yang hanya ditulis tidak lebih dari satu paragraf. Tujuan berita kilat sebagai tambahan informasi yang bersifat sekunder. Prinsip penulisan berita kilat: padat, singkat, jelas, dan berisi. Contoh berita kilat dapat dilihat pada Gambar 4 .

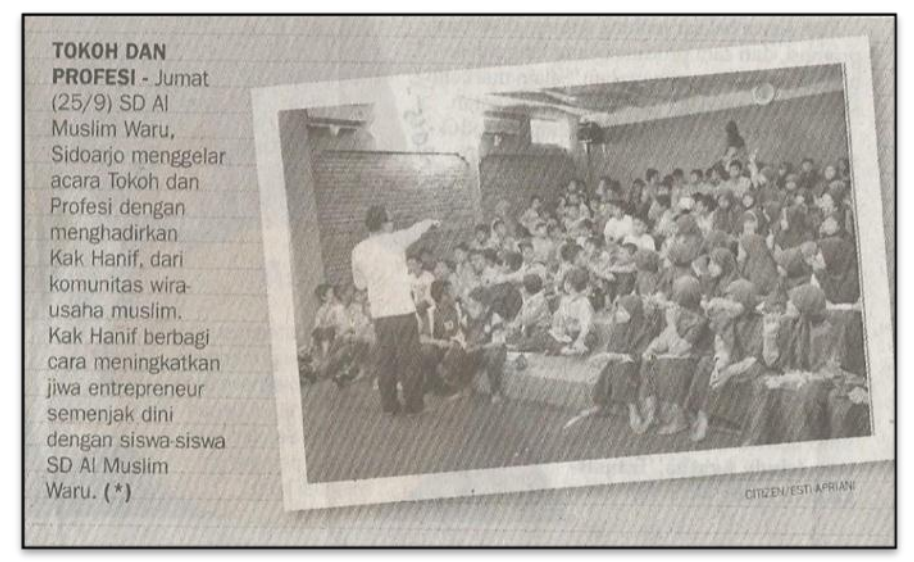

Gambar 4. Contoh berita kilat

(Sumber: Harian Bola, 15 Oktober 2015) 


\section{Terlibat Pengaturan Skor, Ofisial Afsel Diskors FIFA}

Skors enam tahun dijatuhkan FIFA kepada ofisial Asosiasi Sepak Bola Afrika Selatan (Afsel), Lindile Kika, Rabu (14/10). Kika terkait dalam kasus pengaturan skor yang juga melibatkan sindikat di Asia. Mantan Direktur Tim Nasional Asosiasi Sepak Bola Afsel itu dilarang beraktivitas dalam kegiatan sepak bola level nasional dan internasional dalam masa skors. FIFA menyebutkan, Kika terlibat dalam pengaturan skor sejumlah pertandingan persahabatan yang digelar di Afsel pada 2010. Pada tahun itu pula, Afsel menjadi tuan rumah Piala Dunia. Sebelumnya, FIFA melaporkan, seorang makelar judi, Wilson Perumal dan organisasinya, Football $4 \mathrm{U}$, yang bermarkas di Singapura mempunyai hubungan dengan ofisial di Afsel. "Penyelidikan pada Kika dimulai pada November 2014 dalam kaitannya dengan sejumlah pertandingan persahabatan internasional," pernyataan FIFA. (AFP/REUTERS/IYA)

Gambar 5. Contoh berita foto

(Sumber: Surya, 15 Oktober 2015)

Kelima, berita foto. Konsep dasar berita foto adalah "satu foto mewakli seribu kata". Berita foto merupakan bentuk penyampaian berita dengan menggambarkan secara langsung peristiwa yang terjadi melalui foto. Foto dalam jurnalisme berperan sebagai memperjelas dan melukiskan isi berita, sehingga membawa pembaca pada situasi atau lokasi kejadian di mana peristiwa terjadi (Tamburaka, 2013: 108-109). Contoh berita foto dapat dilihat pada Gambar 5.

Keenam, berita warga. Berita warga atau yang lebih dikenal dengan citizen journalist merupakan berita yang ditulis atau disampaikan oleh masyarakat umum (bukan wartawan) tantang berbagai macam peristiwa yang terjadi disekitar. Kemajuan teknologi informasi dan komunikasi, serta faktor kedekatan masyarakat dengan sumber berita menjadi nilai lebih dalam penyampaian berita warga. Contoh berita warga dapat dilihat pada Gambar 6. 
Degita Danur Suharsono, Mengenal Berita Kontemporer...(hal 225-239)

\author{
Rabu 11 Nov 2015, 11:22 WIB \\ Truk Trailer Tabrak Pembatas Jalan dan Terjun ke Jurang \\ di Tol Semarang
}

Angling Adhitya Purbaya - detikNews

Semarang - Truk bermuatan bubuk gula alkohol (sorbitol powder) terguling di tol Jatingaleh-Manyaran Semarang dan masuk ke jurang. Warga yang mengetahui kejadian tersebut langsung melakukan evakuasi terhadap kernet dan sopir.

Peristiwa terjadi sekira pukul 08.00 WIB. Saat itu truk trailer bernopol B 9112 TW melaju dari arah Jatingaleh menuju Manyaran. Namun setelah melintas di atas terowongan Jalan Pawiyatan Luhur atau dekat dengan IKIP Veteran Semarang, truk menabrak pembatas jalan dan terguling masuk ke jurang sedalam 10 meter.

"Saya dengar benturan keras sekali terus ada teriakan minta tolong. Orang-orang sini langsung datang," kata satpam IKIP Veteran Semarang, Santoso di lokasi kejadian, Rabu $(11 / 11 / 2015)$.

Teriakan yang didengar Santoso ternyata berasal dari kernet truk, Suharna. la berteriak meminta tolong karena sopir, Andi Gusnaeni sudah lemas tidak sadarkan diri dengan luka di kepala. Warga langsung membantu evakuasi dan segera membawa dua korban ke rumah sakit.

"Warga dan kernet bawa sopir ke RSUP dr Kariadi naik angkot," ujar Santoso.

Menurut keterangan kernet, ketika truknya melewati atas terowongan dan berada di KM

Gambar 6. Contoh berita warga

(Sumber: detik.com, 11 November 2015)

Ketujuh, berita online. Berita online dan berita warga memiliki kesamaan memanfaatkan teknologi komunikasi dan informasi. Perbedaanya terletak pada siapa yang menulis atau menyampaikannya, jika berita warga ditulis atau disampaikan oleh warga (bukan wartawan), sedangkan berita online ditulis dan disampaikan oleh wartawan dari media massa. Berita online memiliki kelebihan pada faktor kecepatan penyampaian informasi. Contoh berita online dapat dilihat pada Gambar 7. 
Rabu 11 Nov 2015, 11:22 WIB

\section{Truk Trailer Tabrak Pembatas Jalan dan Terjun ke Jurang}

\section{di Tol Semarang}

Angling Adhitya Purbaya - detikNews

Semarang - Truk bermuatan bubuk gula alkohol (sorbitol powder) terguling di tol Jatingaleh-Manyaran Semarang dan masuk ke jurang. Warga yang mengetahui kejadian tersebut langsung melakukan evakuasi terhadap kernet dan sopir.

Peristiwa terjadi sekira pukul 08.00 WIB. Saat itu truk trailer bernopol B 9112 TW melaju dari arah Jatingaleh menuju Manyaran. Namun setelah melintas di atas terowongan Jalan Pawiyatan Luhur atau dekat dengan IKIP Veteran Semarang, truk menabrak pembatas jalan dan terguling masuk ke jurang sedalam 10 meter.

"Saya dengar benturan keras sekali terus ada teriakan minta tolong. Orang-orang sini langsung datang," kata satpam IKIP Veteran Semarang, Santoso di lokasi kejadian, Rabu $(11 / 11 / 2015)$.

Teriakan yang didengar Santoso ternyata berasal dari kernet truk, Suharna. la berteriak meminta tolong karena sopir, Andi Gusnaeni sudah lemas tidak sadarkan diri dengan luka di kepala. Warga langsung membantu evakuasi dan segera membawa dua korban ke rumah sakit.

"Warga dan kernet bawa sopir ke RSUP dr Kariadi naik angkot," ujar Santoso.

Menurut keteranqan kernet, ketika truknya melewati atas terowongan dan berada di KM

Gambar 7. Contoh berita online

(Sumber: detik.com, 11 November 2015)

Kedelapan, berita anekdot. Berita anekdot merupakan bentuk tulisan berita dengan teknik penulisan dan penyampaian yang lucu dan menarik. Penulisan dan penyampaian berita anekdot yang lucu dan menarik diharapkan dapat menarik minat khalayak umum. Contoh berita anekdot dapat dilihat pada Gambar 8. 


\section{PPP Kepincut Golkar}

Sepandai-pandainya berbuat kelicikan dan kecurangan, pasti akan ketahuan juga. Apalagi soal perselingkuhan. Sepandai apa pun dalam merancang strategi kencan, tetap saja ketahuan. Sama halnya seperti yang dialami Markonah, 35, warga Kedungkandang, Kota Malang. Markonah sejatinya sudah menikah dengan Markucel, 37. Dari hasil pernikahannya, mereka memiliki dua anak, sebut saja Bunga (12) dan Mawar (9).

Namun sayang, selama menikah, Markonah kerap merasa kurang bahagia dengan kehidupan rumah tangganya bersama Markucel. Sebab, Markucel tipe laki-laki yang pelit. Jika punya uang dari hasil berjualan sayur di Pasar Besar, sering tidak diberikan kepada Markonah. Alhasil kendati sudah punya suami, dia merasa bagai sINGLE FIGHTERsaja. Markonah sering menafkahi kedua anaknya sendirian. Padahal dalam hal cinta, Markonah cinta sekali kepada Markucel. Apalagi Markonah adalah anggota PPP (perempuan pecinta pria).

Sering mengidap penyakit gegana (gelisah galau merana), membuat Markonah sering berselancar di FАС ввоок. Dari aktivitasnya di dunia maya, Markonah yang berwajah macan (manis dan cantik) ini berkenalan dengan brondong, Srontol, 25. Srontol merupakan salah satu karyawan di perusahaan swasta. Srontol merupakan pria anggota Golkar (golongan pria kekar).

Karena sering CHATTING, membuat keduanya dimabuk kepayang, kendati belum sekalipun kopi darat. Setelah berkomunikasi sekitar 3 bulan, akhirnya Markonah janjian bertemu dengan Srontol di salah satu hotel bintang tiga di Kota Malang. Tak dinyana, kendati beda usianya cukup jauh, tapi kedua manusia beda jenis kelamin ini ternyata cocok.

Bisa ditebak jika dua insan beda jenis kelamin bertemu di kamar hotel. Hanya mereka, Tuhan, dan kasur yang berderit menjadi saksi bagaimana keduanya melakukan berbagai macam variasi Gerindra (gerakan indah penuh hasrat). Jika sudah melakukan Gerindra, sudah pasti Markonah lupa anak dan suaminya. Yang ada hanya bagaimana menciptakan KPU (kegiatan penuh umek) yang dahsyat dan menguras energi.

Ketagihan dengan aksi Gerindra dari Srontol, membuat Markonah sering melakukan KPU. Namun dasar Markonah ceroboh, usai melakukan kegiatan enak itu, dia lupa membuang BILL dari hotel. Walah, Markucel

Gambar 8. Contoh berita anekdot

(Sumber: Radar Malang, online, 10 Oktober 2015)

Berdasarkan uraian dan contoh jenis-jenis berita kontemporer tersebut, guru dan siswa dapat menggunakannya dalam pembelajaran bahasa Indonesia, khususnya materi teks berita. Ada beberapa langkah yang dapat dilakukan guru dan siswa untuk mengembangkan berita kontemporer dalam materi pembelajaran teks berita. Pertama, guru dan siswa mengenali konsep berita kontemporer terlebih dahulu. Kedua, guru dan siswa mengetahui karakteristik berita kontemporer, langkah ini bertujuan untuk membedakan berita kontemporer dengan berita konvensional. Ketiga, siswa memproduksi berita kontemporer sesuai dengan kaidah penulisan yang baik dan benar. 


\section{SIMPULAN}

Ada beberapa hal yang dapat ditulis sebagai simpulan. Berita kontemporer merupakan laporan tercepat mengenai suatu peristiwa/fakta yang disampaikan ke khalayak umum dengan memanfaatkan kemajuan teknologi komunikasi dan informasi. Berita kontemporer dapat digunakan sebagai inovasi pembelajaran bahasa Indonesia, khususnya materi teks berita. Berita kontemporer dapat menjadi salah satu dasar bagi siswa untuk menghadapi era globalisasi.

Lebih lanjut, penulis menyarankan guru bahasa Indonesia sebaiknya membuka diri menerima paradigma baru dalam pembelajaran bahasa, khususnya teks berita. Guru dapat mencoba berita kontemporer sebagai salah satu inovasi pembelajaran dalam mengajarkan berita kepada siswa. Siswa dapat memanfaatkan berita kontemporer sebagai tambahan ilmu pengetahuan dan menyiapkan diri dalam menghadapi era globalisasi serta memasuki MEA.

\section{DAFTAR RUJUKAN}

Asmuruf, S. 2015. Media Konvensional VS Media Online. (Online). http://m.kompasmania.com/septhy/media-konvensional-vs-mediaonline 54f7beafa33311441d8b48c0. Diakses pada tanggal 26 Juli 2016.

Kovach, Bill dan Tom Rosentiel. 2001. Elements Journalism. New York: Crown Publisher.

Kurnia, Septian Santana. 2005. Jurnalisme Kontemporer. Jakarta: Yayasan Obor Indonesia.

Saryono, Djoko. 1997. Ragam Tulisan Jurnalistik. Malang: Departemen Pendidikan dan Kebudayaan Institut Keguruan dan Ilmu Pendidikan Malang Bagian Proyek Operasi dan Perawatan Fasilitas Proyek IKIP Malang.

Setiati, Eni. 2005. Ragam Jurnalistik Baru dalam Pemberitaan. Yogyakarta: Penerbit ANDI.

Suhandang, Kustadi. 2010. Pengantar Jurnalistik, Seputar Organisasi, Produk, dan Kode Etik. Bandung: Nuansa.

Sumadiria, AS Haris. 2008. Jurnalistik Indonesia: Menulis Berita dan Feature. Bandung: Simbiosa Rekatama Media.

Tamburaka, Apriadi. 2013. Literasi Media: Cerdas Bermedia Khalayak Media Massa. Jakarta: PT Raja Grafindo Persada. 
Degita Danur Suharsono, Mengenal Berita Kontemporer...(hal 225-239) 